\title{
PERSEPSI MAHASISWA MENGENAI KENYAMANAN RUANG BELAJAR SELAMA MASA PERKULIAHAN
}

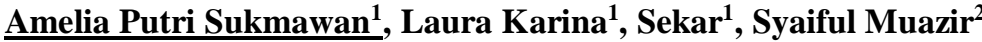 \\ ${ }^{1}$ Mahasiswa, Program Studi Arsitektur, \\ Fakultas Teknik Universitas Tanjungpura, Indonesia \\ ${ }^{2}$ Dosen Program Studi Arsitektur, \\ Fakultas Teknik Universitas Tanjungpura, Indonesia
}

Email korespondensi: sukmawamel@gmail.com

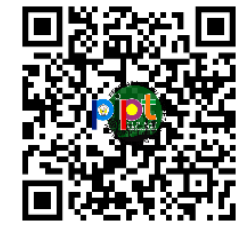

10.26418/pipt.2021.31

\begin{abstract}
Abstrak
Coronavirus Disease (Covid-19) merupakan penyakit menular yang disebabkan oleh virus SARSCoV-2 dan memaksa kita untuk melakukan banyak hal di dalam ruangan atau tanpa kontak fisik dan harus melakukan jaga jarak antar sesama. Pemerintah membuat langkah untuk memutus rantai penyebaran Covid-19 di Indonesia dengan cara menerapkan sistem BDR (belajar dari rumah). Aktivitas pembelajaran daring/BDR berfungsi untuk menjaga social distancing serta physical distancing. Permasalahan yang muncul dari diterapkannya sistem BDR ini ialah apakah mahasiswa merasa ruangan yang mereka gunakan cukup memberikan kenyamanan selama masa BDR? Penelitian ini dilakukan dengan tujuan untuk mengetahui apakah kondisi ruang belajar mahasiswa dirasa nyaman dan mampu menambah konsentrasi selama masa perkuliahan. Subjek penelitian ini adalah mahasiswa yang menjalankan BDR dari Jurusan Arsitektur Universitas Tanjungpura angkatan 2018, 2019, dan 2020. Dengan kondisi tempat tinggal mahasiswa yang berbeda-beda, terdapat aspek yang dapat mendukung aktivitas pembelajaran mahasiswa untuk beraktivitas dengan baik selama melaksanakan BDR, salah satunya adalah kenyamanan ruang.
\end{abstract}

Kata kunci: Kenyamanan ruang, BDR, mahasiswa, covid-19, kuliah daring

\section{PENDAHULUAN}

Kenyamanan ruang merupakan salah satu aspek penting yang dapat menentukan produktivitas kegiatan yang berlangsung di dalamnya termasuk aktivitas pembelajaran. Sebagai pemenuhan hak peserta didik untuk mendapatkan pelayanan selama darurat pandemik Covid-19. Pembelajaran dilakukan di rumah BDR atau biasa disebut daring sebagaimana tercantum di dalam surat edaran Kemendikbud (2020) Nomor 4 Tahun 2020 tentang Pelaksanaan Kebijakan Pendidikan dalam Masa Darurat Covid-19 dan diperkuat oleh Kemendikbud (2020) SE Sekjen Nomor 15 Tahun 2020 tentang Pedoman Pelaksanaan BDR Selama Darurat Covid-19. BDR belajar dari rumah/daring dilakukan pelajar atau mahasiswa tidak dapat bertatap muka secara langsung untuk menjaga penyebaran dan memutus rantai penularan Covid-19 sehingga mahasiswa dan tenaga pendidik tetap dapat menjalani aktivitas belajar mengajar dengan baik, aman, dan nyaman. Menurut Kementerian Pendidikan dan Kebudayaan (2020) dikatakan bahwa baik di tempat sekolah maupun di rumah, penataan lingkungan belajar yang kondusif dan layak sangat dibutuhkan untuk membantu konsentrasi dan efektivitas belajar mahasiswa didik. Tidak hanya berdasar pada lingkungan fisik, namun juga mencakup pada tanggapan mahasiswa terhadap kondisi ruang belajarnya. Ruang belajar yang baik dapat diciptakan dengan beberapa aspek yaitu menyediakan area belajar yang jauh dari polusi udara, pencahayaan yang baik, suhu ruangan, warna dinding, serta tersedianya meja dan kursi dengan sirkulasi gerak yang bebas. Metode pelaksanaan BDR merupakan kegiatan pembelajaran yang penerapannya dilakukan secara berjarak dari rumah masingmasing mahasiswa sehingga disebut pula sebagai Pembelajaran Jarak Jauh atau PJJ. Metode pembelajaran seperti ini merupakan formasi dimana pembelajaran dilakukan secara daring oleh mahasiswa dari tempat tinggalnya masing-masing. Dalam hal ini 
diperlukan penyesuaian bagi setiap mahasiswa untuk nyaman dalam kondisi ruang yang tersedia selama BDR, dimana pada beberapa kondisi dapat dikatakan bahwa ruang yang digunakan tidak sesuai ataupun tidak nyaman sebagai ruang belajar.

\section{METODOLOGI}

Metode penelitian ini menggunakan pendekatan metode survei dengan jenis penelitian sifat deskriptif. Arikunto (2011) menjelaskan bahwa pendekatan survei dengan sifat deskriptif memiliki tujuan untuk menggambarkan atau mendeskripsikan keadaan serta fenomena yang terjadi. Sedangkan menurut Setyosari (2012), penelitian deskriptif ialah penelitian yang mendeskripsikan atau menjelaskan dengan kata-kata maupun angka terkait suatu keadaan, peristiwa, dan objek. Penelitian ini menggunakan pendekatan metode survei dengan jenis penelitian sifat deskriptif guna mengkaji persepsi mahasiswa terhadap kenyamanan ruang selama BDR berlangsung, sehingga objek yang dijadikan sasaran ialah ruangan yang menjadi lokasi BDR. Waktu pelaksanaan penelitian dilakukan selama 2 minggu dengan menyebarkan formulir survei berupa kuesioner google form yang ditargetkan kepada mahasiswa-mahasiswi Program Studi Arsitektur Tanjungpura angkatan 2018, 2019, dan 2020 berjumlah 116 orang. Adapun variabel dan unit amatan yang digunakan pada penelitian ini disajikan pada Tabel 1 .

Tabel 1: Kerangka Teoritis Kenyamanan Ruang

\begin{tabular}{|c|c|c|c|}
\hline No & Peneliti & Faktor & Variabel \\
\hline 1. & $\begin{array}{l}\text { Prasasto } \\
\text { Satwiko } \\
\text { (2009) }\end{array}$ & Faktor Fisik & $\begin{array}{c}\text { Termal } \\
\text { Akustik } \\
\text { Visual }\end{array}$ \\
\hline \multirow[t]{3}{*}{2.} & \multirow[t]{3}{*}{$\begin{array}{c}\text { Katharine } \\
\text { Kolbaca } \\
(2003)\end{array}$} & $\begin{array}{l}\text { Faktor Fisik } \\
\quad \text { dan } \\
\text { Lingkungan }\end{array}$ & $\begin{array}{c}\text { Temperatur } \\
\text { Warna } \\
\text { Pencahayaan } \\
\text { Kebisingan }\end{array}$ \\
\hline & & $\begin{array}{c}\text { Faktor } \\
\text { Psikospiritual } \\
\end{array}$ & - \\
\hline & & $\begin{array}{c}\text { Faktor } \\
\text { Sosiokulturan } \\
\end{array}$ & - \\
\hline 3. & $\begin{array}{l}\text { Tika } \\
\text { Ainunnisa } \\
\text { F. (2018) }\end{array}$ & Faktor Fisik & $\begin{array}{l}\text { Warna Ruang } \\
\text { Ukuran \& Bentuk } \\
\text { Suara }\end{array}$ \\
\hline
\end{tabular}

\begin{tabular}{|c|c|l|l|}
\hline & & & $\begin{array}{l}\text { Temperature } \\
\text { Pencahayaan }\end{array}$ \\
\hline 4. & $\begin{array}{c}\text { Lipsmeire } \\
\text { Georg } \\
(1980)\end{array}$ & Faktor Fisik & $\begin{array}{l}\text { Kenyamanan } \\
\text { Termal } \\
\text { Kenyamanan Visual } \\
\text { (cahaya) } \\
\text { Kenyamanan Audial } \\
\text { (akustika) }\end{array}$ \\
\hline 5. & $\begin{array}{c}\text { Aghni dan } \\
\text { Edward } \\
(2020)\end{array}$ & Faktor Fisik & $\begin{array}{l}\text { Termal/Penghawaan } \\
\text { Visual/Pandangan } \\
\text { Akustik }\end{array}$ \\
\hline
\end{tabular}

Sumber: Penulis, 2021

Pengumpulan jawaban dari responden menggunakan skala likert sebagai alat ukur perhitungan skor dari kategori pilihan jawaban yang telah disediakan. Teknik analisis data menggunakan analisis statistik deskriptif, dengan menjabarkan penjelasan hasil dari kuesioner dilengkapi dengan skor persentase dan frekuensi. Penelitian ini dilaksanakan dengan mengacu pada isu dan relevansi berikut:

1. Penerapan sosial dan physical distancing dalam mencegah penyebaran wabah Covid-19.

2. Pemerintah mengeluarkan metode pelaksanaan program Belajar dari Rumah (BDR).

3. Kenyamanan individu terkait kondisi ruang selama BDR.

4. Pemilihan judul dan tema mendalam terkait kenyamanan ruang.

5. Penetapan cakupan subjek penelitian: Mahasiswa/i Arsitektur angkatan 2018, 2019, dan 2020.

Penelitian ini bertujuan untuk mengetahui sudut pandang mahasiswa/i terkait kondisi kenyamanan ruang selama BDR. Penelitian dilaksanakan dengan tahapan berikut:

1. Pemilihan variabel komponen kenyamanan ruang.

2. Perumusan pertanyaan-pertanyaan kuisioner dari variabel unit amatan.

3. Menyebarkan kuisioner kepada subjek penelitian/responden.

4. Mengumpulkan dan memaparkan data hasil jawaban dari responden berisi frekuensi dan persentase.

5. Analisis deskriptif dari hasil data kuisioner. 
6. Menyimpulkan hasil analisis dari dominan jawaban yang telah diisi oleh responden.

Tempat penelitian merupakan lokasi dimana studi penelitian dilaksanakan dalam memperoleh pemecahan masalah berlangsung (Darmadi, 2014). Lokasi penelitian ini ialah berbagai ruang di kediaman masing-masing mahasiswa selama kegiatan BDR berlangsung. Penyebaran survei diselenggarakan pada bulan Mei mulai dari tanggal 5 hingga 19 Mei 2021. Harapan luaran penelitian ini agar menjadikan hasil responden terhadap acuan sudut pandang mahasiswa/i mengenai kenyamanan ruang BDR.

\section{Populasi}

Arikunto (1998) menyebutkan bahwa populasi merupakan keseluruhan subjek penelitian. Adapun subjek atau populasi dalam penelitian ini ialah mahasiswa yang sedang kuliah di Program Arsitektur Universitas Tanjungpura dan berstatus aktif selama BDR berlangsung dengan cakupan angkatan 2018, 2019, dan 2020. Sampel penentuan sampel menggunakan teknik purposive random sampling, yaitu teknik pengambilan sampel dengan random. Sampel merupakan bagian dari jumlah populasi dan karakteristik tertentu (Sugiyono, Metode Penelitian Pendidikan Pendekatan Kuantitatif, Kualitatif, dan R\&D , 2014) sehingga sampel dalam penelitian ini ditentukan melalui penggunaan rumus Slovin sebagai berikut:

$$
n=N 1+N e 2
$$

Keterangan:

$\mathrm{n}=$ ukuran sampel

$\mathrm{N}=$ jumlah populasi

$\mathrm{E}=5 \%$

Tabel 2: Jumlah Sampel

\begin{tabular}{|c|c|c|}
\hline Angkatan & $\begin{array}{c}\text { Jumlah } \\
\text { Populasi }\end{array}$ & Jumlah Sampel \\
\hline 2018 & 44 & 40 \\
\hline 2019 & 39 & 36 \\
\hline 2020 & 44 & 40 \\
\hline
\end{tabular}

Dari Tabel 2 di atas didapatkan total 116 sampel dengan 40 sampel dari angkatan 2018, 36 sampel dari angkatan 2019, dan 40 orang dari angkatan 2020 Program Studi Arsitektur Universitas Tanjungpura. Variabel penelitian dan unit amatan yang diteliti ialah:

- Variabel pengaruh (independent variabels): Ruang yang dijadikan tempat perkuliahan online oleh mahasiswa selama pandemi.

- Variabel terpengaruh (dependent variables): Persepsi mahasiswa terkait kenyamanan ruang, dengan variabel kenyamanan yang meliputi termal, akustika, warna, pencahayaan, serta ukuran dan bentuk.

Tabel 3: Indikator Unit Amatan

\begin{tabular}{|c|c|}
\hline $\begin{array}{c}\text { Variabel } \\
\text { Penelitian }\end{array}$ & Indikator Unit Amatan \\
\hline \multirow{3}{*}{ Termal } & Kondisi penghawaan ruang saat BDR \\
\cline { 2 - 2 } & Bukaan ruangan terkait sirkulasi \\
\cline { 2 - 2 } & $\begin{array}{c}\text { Penggunaan penghawaan alami atau } \\
\text { buatan }\end{array}$ \\
\hline Akustika & Kebisingan di sekitar ruang BDR \\
\cline { 2 - 2 } & Tingkat kebisingan terhadap kenyamanan \\
\hline Warna & $\begin{array}{c}\text { Dominan warna ruang yang dapat } \\
\text { membantu fokus BDR }\end{array}$ \\
\hline Penerangan & Jenis penerangan alami atau buatan \\
\cline { 2 - 3 } & $\begin{array}{c}\text { Tingkat penerangan terhadap } \\
\text { kenyamanan }\end{array}$ \\
\hline Ukuran dan & $\begin{array}{c}\text { Pengaruh ukuran ruangan terkait } \\
\text { kentuk }\end{array}$ \\
\hline
\end{tabular}

Sumber: Penulis, 2021

Adapun rincian tahap prosedur penelitian yang dilakukan penulis agar penelitian berjalan dengan lancar sesuai susunan yang berurutan adalah:

a. Menetapkan tema dan fokus penelitian.

b. Mengidentifikasi masalah yang akan diteliti.

c. Mengumpulkan studi literatur terkait dengan fokus penelitian yang diambil melalui buku serta jurnal. 
d. Pembuatan pertanyaan-pertanyaan dalam angket dari topik variabel yang telah dipilah dan sesuai dengan indikator unit amatan. Jenis pertanyaan merupakan pertanyaan tertutup menggunakan skala likert dan terdapat pertanyaan terbuka untuk mendalami topik penelitian.

e. Menyebarkan angket kepada sasaran subjek penelitian melalui google form secara online dalam rentang waktu satu sampai dua minggu.

f. Mengumpulkan data hasil angket berupa frekuensi dan persentase yang telah diisi oleh responden.

g. Menganalisis data menggunakan analisis statistik deskriptif dengan memaparkan hasil jawaban responden.

\section{Teknik Pengumpulan Data}

Agar data yang diperoleh dikatakan valid atas kebenarannya, maka dalam penelitian ini menggunakan metode survei angket yang disebarkan langsung kepada subjek yang bersangkutan secara online melalui google form. Jenis kuisioner bersifat tertutup dengan berisi sejumlah pertanyaan tertulis yang telah diberi opsi jawaban namun pada beberapa pertanyaan responden dapat menuliskan jawaban tersendiri secara lebih detail. Jawaban yang telah diperoleh dari survei google form berupa skor yang menggunakan alat ukur skala likert. Pertanyaan pada formulir survei berupa pernyataan dengan opsi jawaban berupa kategori-kategori dengan memiliki skor nilai angka agar mempermudah dalam mengolah data. Adapun skor nilai pada jawaban formulir sebagai berikut:

Tabel 4: Skor Jawaban

\begin{tabular}{|c|c|}
\hline Kategori & Skor Jawaban \\
\hline Sangat Tidak Setuju & 1 \\
\hline Tidak Setuju & 2 \\
\hline Ragu-ragu & 3 \\
\hline Setuju & 4 \\
\hline Sangat Setuju & 5 \\
\hline
\end{tabular}

Sumber: Penulis, 2021

\section{Teknik Analisis Data}

Menurut Sugiyono (2009), analisis merupakan kegiatan mengumpulkan, mengolah, dan mendeskripsikan data yang terkumpul. Berdasarkan jenis penelitian deskriptif dengan pengumpulan data melalui angket, teknik analisis data yang digunakan ialah dengan mengelompokkan hasil jawaban angket melalui analisis statistik deskriptif. Analisis statistik deskriptif digunakan dengan cara mendeskripsikan atau menggambarkan data yang telah terkumpul sebagaimana adanya, tanpa merubah hasil jawaban asli dari sumbernya. Jenis statistik yang digunakan dalam penelitian ini adalah skor frekuensi dan persentase.

\section{HASIL DAN PEMBAHASAN}

Kenyamanan ruang dipercaya dapat memengaruhi suasana dalam beraktivitas sehingga kegiatan dilakukan dengan lancar dan produktif. Dalam masa pandemi Covid19, Kemendikbud mengedarkan surat Nomor 4 Tahun 2020 tentang pelaksanaan kebijakan pendidikan dalam masa darurat Covid-19 dan diperkuat dengan SE Sekjen Nomor 15 tahun 2020 tentang Pedoman Pelaksanaan Belajar dari Rumah (BDR) selama darurat Covid-19. Sehingga kenyamanan ruang dapat diidentifikasi oleh beberapa ahli. Konsep tentang kenyamanan (comfort) sangat sulit untuk didefinisikan karena lebih merupakan penilaian responsif individu (Oborne, 1987). Rumusan komponen variabel kenyamanan ruang yang akan diteliti enam dalam kegiatan BDR dirasa sangat penting sebagai faktor agar seseorang dapat fokus bekerja dan/atau belajar. Aspek yang menjadi variabel penelitian didapatkan dari beberapa ahli dan telah dipilah, yaitu kenyamanan termal, kenyamanan kebisingan, kenyamanan pencahayaan, kenyamanan warna, dan kenyamanan ukuran bentuk. 


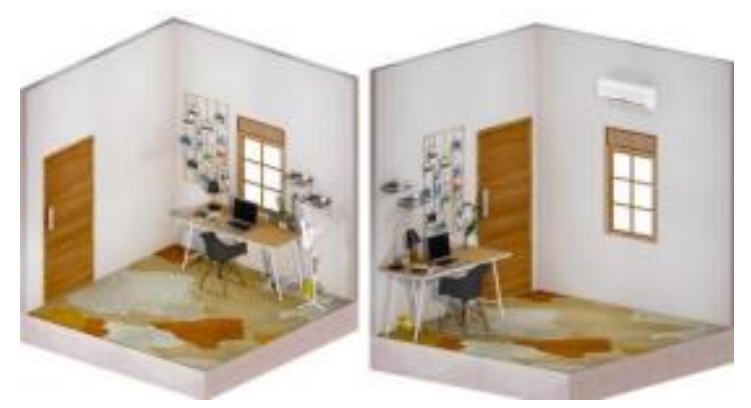

Sumber: Penulis, 2021

Gambar 1: Visualisasi 3D ruang 3x3 dengan kipas angin (kiri) dan ruang $3 \times 3$ dengan $\mathrm{AC}$ (kanan)

a. Aspek Termal

Kenyamanan termal merupakan kondisi ideal dimana seseorang dapat merasa nyaman untuk melakukan aktivitas dan kegiatan dengan tingkat suhu tertentu di lingkungannya.

b. Aspek Akustika/Kebisingan

Menurut Buchari (2017), kebisingan dapat disebut pula sebagai suara yang tidak dikehendaki yang mengganggu kenyamanan dan kesehatan bahkan mengakibatkan ketulian.

c. Aspek Warna

Menurut Lenggosari (2018), warna adalah unsur yang bisa menciptakan mood atau suasana ruang. Menurut Eiseman (2000), warna merupakan bentuk komunikasi non verbal yang berfungsi sebagai metode penyampaian pesan dan makna yang paling instan atau menghasilkan pengaruh dengan seketika.

d. Aspek Pencahayaan/penerangan

Pencahayaan/penerangan merupakan aspek yang penting dalam menentukan kenyamanan suatu ruang. Menurut Lasa (2005), cahaya yang masuk ke dalam ruangan ada dua macam, yaitu:

1) Penerangan alami: Cahaya alami yang ditimbulkan oleh matahari.

2) Penerangan buatan (artificial light): Berbentuk berupa cahaya dari alat yang diciptakan oleh manusia.

e. Aspek Ukuran dan Bentuk
Sebagai pembentuk suatu ruang, ukuran dan bentuk merupakan suatu variabel dengan nilai yang bersifat tetap dan tidak berubah.

\section{KESIMPULAN}

Kesimpulan akhir yang dapat ditarik dari hasil penelitian yang telah dilakukan adalah diketahui bahwa tempat pelaksanaan perkuliahan responden selama BDR paling dominan adalah di kamar, dengan ukuran kamar paling banyak sebesar $3 \times 3$ dan $3 \times 4$. Untuk penghawaan ruangan, jumlah jendela dan ventilasi di ruang belajar masing-masing responden juga beragam, namun dominan pada jumlah 1 jendela/ventilasi dengan 1 kipas diikuti oleh 1 jendela/ventilasi dengan 1 AC. Kemudian terdapat warna ruang belajar para responden, dengan warna ruang dominan adalah putih dan kemudian diikuti warna cream dan biru. Untuk penghawaan, sebagian besar responden merasa perlu untuk menggunakan penghawaan buatan berupa pendingin ruangan untuk mencapai tingkat kenyamanan termal. Mengenai pengukuran aspek kebisingan, hasil menunjukkan bahwa dominan responden merasa tidak menemukan/merasakan kebisingan di dalam ruang belajar yang digunakan namun terdapat gangguan kebisingan dari ruangan lain. Terhadap aspek pencahayaan sebagian besar responden setuju bahwa dengan kondisi lampu yang dimatikan, kondisi ruang dianggap masih tetap terasa nyaman sehingga diketahui bahwa penggunaan pencahayaan alami dikatakan lebih nyaman. Dari hasil penelitian yang telah dilakukan lakukan, dapat disimpulkan bahwa sebagian besar mahasiswa responden merasa sudah cukup nyaman dengan kondisi ruang belajar yang masing-masing mereka gunakan. Aspek kenyamanan yang terdiri dari komponen variabel fisik ruang seperti penghawaan, kebisingan, pencahayaan, penggunaan warna serta ukuran juga semuanya dirasa sudah cukup terpenuhi untuk mencapai kenyamanan ruang yang dikehendaki oleh penggunanya tanpa diperlukan perubahan yang drastis. 


\section{UCAPAN TERIMA KASIH}

Terima kasih kepada semua pihak yang telah terlibat baik secara langsung maupun tidak langsung selama proses pengerjaan penelitian ini, dengan segala hormat kami penulis menyampaikan terima kasih atas bantuan dan kesempatan yang telah diberikan.

\section{DAFTAR PUSTAKA}

Aghniya, A. H., \& Pandelaki, E. E. (2020). Kenyamanan pada Ruang dalam Perkantoran. IMAJI, 9(5), 603.

Arikunto, S. (1998). Prosedur Penilaian. Jakarta: Rineka Cipta.

Arikunto, S. (2011). Prosedur Penelitian Sebuah Pendekatan Praktik. Jakarta: Rineka Cipta.

Buchari. (2017). Kebisingan Industri dan Hearing Conservation Program. Repository USU.

Darmadi, H. (2014). Metode Penelitian Pendidikan Sosial. Bandung: Alfabeta.

Eiseman, L. (2000). Pantone: Guide to Communicating with Color. Ohio: How Books.

Fitria, T. A. (2018). Pengaruh Setting Ruang terhadap Perilaku Pengguna dengan Pendekatan Behavioral Mapping. Jurnal Arsitektur dan Perencanaan, 1(2), 183-206.

Kemendikbud. (2020). Menciptakan Lingkungan yang Nyaman Selama BDR Bagi Anak. Retrieved from Paudpedia:

https://paudpedia.kemdikbud.go.id/

Kemendikbud. (2020). Surat Edaran Mendikbud No 4 Tahun 2020 tentang Pelaksanaan Kebijakan Pendidikan Dalam Masa Darurat Penyebaran Corona Virus Disease. Retrieved from

https://pusdiklat.kemdikbud.go.id/sur at-edaran-mendikbud-no-4-tahun2020-tentang-pelaksanaan-kebijakanpendidikan-dalam-masa-daruratpenyebaean-corona-virus-diseasecovid-1-9/

Kemendikbud. (2020). Surat Edaran Sekretaris Jendral Mendikbud Nomor 15 Tahun 2020 Tentang Pedoman Peyelanggaraan Balajar Dari Rumah Dalam Masa Darurat Penyebaran Corona Virus Disease (Covid-19). Retrieved from https://www.kemdikbud.go.id/

Kolbaca, K. (2003). Comfort Theory and Practice: A Vision for Holistic Health. New York: Spinger Publishing Company.

Lasa. (2005). Manajemen Perpustakaan. Yogyakarta: Gama Media.

Lenggosari. (2018). Paduan Warna Menarik untuk Rumah. Jakarta: Penebar Swadaya.

Lippsmeier, G. (1980). Tropenbau Building in The Tropis. Munchen: Verlag Georg D.W.

Oborne, D. J. (1987). Ergonomic at Work: Human Factors in Design and West.

Satwiko, P. (2009). Pengertian Kenyamanan dalam Suatu Bangunan. Yogyakarta: Wignjosoebroto.

Setyosari, P. (2012). Metode Penelitian Pendidikan dan Pengembangan. Jakarta: Kencana.

Sugiyono. (2009). Metode Penelitian Pendidikan Pendekatan Kuantitatif, Kualitatif, dan $R \& D$. Bandung: Alfabeta.

Sugiyono. (2014). Metode Penelitian Pendidikan Pendekatan Kuantitatif, Kualitatif, dan $R \& D$. Bandung: Alfabeta. 